\title{
PENGARUH GAYA KEPEMIMPINAN DAN KOMPENSASI TERHADAP KEPUASAN KERJA DAN KINERJA PEGAWAI TENAGA KONTRAK
}

\author{
Sri Rustilah ${ }^{1}$ \\ ${ }^{1}$ Program Studi Manajemen Pascasarjana Universitas GaluhCiamis \\ email:srustilah@gmail.com
}

\author{
Article History : \\ Received7February 2018 \\ Recieved in revished form \\ 21February 2018 \\ Acepted 6May 2018 \\ Available offline 20 May 2018 \\ Available online 20 May 2018
}

Language Transcript :

Indonesia

Key Words :

Gaya Kepemimpinan

Kompensasi

Kepuasan Kerja

Kinerja Tenaga Kontrak

\begin{abstract}
Tujuan dari penelitian ini adalah untuk melihat pengaruh gaya kepemimpinan dan kompensasi terhadap kinerja melalui kepuasan kerja pegawai Tenaga Kontrak. Metode yang digunakan adalah metode deskriptif. Sedangkan untuk menganalisis data yang diperoleh digunakan analisis korelasi dan regresi ganda menggunakan program SPSS versi 16.00 for windows. Hasil dari penelitian menunjukkan bahwa: 1) Pengaruh pengaruh gaya kepemimpinan terhadap kepuasan kerja diperoleh nilai $r$ sebesar 0,361, nilai kd sebesar 13\%, dan nilai hasil uji $t$ sebesar 2,807 yang berarti $t_{\text {hitung }}>t_{\text {tabel }}$ sehingga hipotesis dapat diterima karena teruji kebenarannya. 2) Pengaruh kompensasi terhadap kepuasan kerja diperoleh nilai $r$ sebesar 0,327, nilai $k d$ sebesar 10,7\%, dan nilai hasil uji $t$ sebesar 2,406 yang berarti $t_{\text {hitung }}>t_{\text {tabel }}$ sehingga hipotesis dapat diterima karena teruji kebenarannya. 3) Pengaruh gaya kepemimpinan terhadap kinerja diperoleh nilai $r$ sebesar 0,315, nilai kd sebesar 9,9\%, dan nilai hasil uji t sebesar 3,036 yang berarti $t_{\text {hitung }}>t_{\text {tabel }}$ sehingga hipotesis dapat diterima karena teruji kebenarannya. 4) Pengaruh kompensasi terhadap kinerja diperoleh nilai $r$ sebesar 0,384, nilai $k d$ sebesar 14,8\%, dan nilai hasil uji $t$ sebesar 2,262 yang berarti $t_{\text {hitung }}>t_{\text {tabel }}$ sehingga hipotesis dapat diterima karena teruji kebenarannya. 5) Pengaruh gaya kepemimpinan dan kompensasi terhadap kinerja melalui kepuasan kerja diperoleh nilai $R$ sebesar 0,799, nilai $k d$ sebesar 63,84\%, dan nilai hasil uji F sebesar 8,801 yang berarti $F_{\text {hitung }}>F_{\text {tabel }}$ sehingga hipotesis dapat diterima karena teruji kebenarannya.
\end{abstract}

\section{PENDAHULUAN}

Peningkatan kualitas sumber daya pegawai Rumah Sakit bertujuan untuk mengubah perilaku mereka menjadi perilaku yang lebih mampu melaksanakan aktivitas dibidangnya masing-masing, sehingga dapat mencapai tujuan yang hendak dicapai. Pengembangan sumber daya manusia pada dasarnya adalah peningkatan kinerja pegawai yang mencerminkan kemampuan anggota organisasi dalam bekerja, artinya kinerja masing-masing pegawai dinilai dan diukur menurut kriteria yang sudah ditentukan sebelumnya oleh organisasi. Pada sisi inilah prestasi individu menjadi jaminan bahwa organisasi akan tetap mampu menjawab setiap tantangan perubahan dan bahkan menjangkau setiap kemungkinan perubahan di masa yang akan datang.

Berdasarkan pengamatan, jumlah kunjungan pasien pada Rumah Sakit Umum Daerah Kabupaten Ciamis terutama pasien peserta BPJS meningkat drastis, namun 
pada pelaksanaannya pelayanan kesehatan terhadap pasien dan pengadministrasiannya belum optimal, hal tersebut karena masih rendahnya kinerja pegawai Tenaga Kontrak. Rendahnya kinerja pegawai Tenaga Kontrak disebabkan karena kepuasan kerjadan kinerja pegawai yang rendah sehingga kurang mendorong pada peningkatan kinerja pegawai Tenaga Kontrak itu sendiri dan seluruh pegawai pada umumnya yang berakibat pencapaian tujuan instansi menjadi belum optimal.

Sikap pegawai Tenaga Kontrak belum sepenuhnya sejalan dengan hal tersebut di atas, masih ada kelalaian dalam pelaksanaan tugas sebagaimana peraturan yang telah ditetapkan seperti datang tidak tepat waktu maupun tidak masuk kerja, ada yang jarang bahkan tidak mengisi absensi pada hari kerja, perintah atasan tidak disegerakan sehingga pengerjaan tugas tidak cepat selesai, kurang mematuhi tata tertib serta adanya ketidakpuasan terhadap kompensasi yang diterima.

Meskipun tidak semua pegawai Tenaga Kontrak yang lalai terhadap peraturan dan tidak puas atas apa yang diterimanya, namun hal tersebut telah mempengaruhi kinerja pegawai itu sendiri bahkan kinerja instansi. Kinerja yang dimiliki pegawai cukup rendah tidak seimbang dengan jumlah pasien, sehingga dapat mempengaruhi pada pelayanan. Dengan permasalahan pekerjaan yang begitu kompleks maka RSUD Kabupaten Ciamis memerlukan pegawai yang tepat untuk mencapai tujuan yang diharapkan.

Berdasarkan latar belakang penelitian, maka identifikasi masalah dalam penelitian ini adalah: 1) Banyaknya permasalahan baru dan kompleks yang berkaitan dengan meningkatnya jumlah pasien terutama pasien BPJS. 2) Kurangnya dukungan moril terhadap produktivitas kerja karyawan. 3) Instansi dituntut lebih memotivasi pegawai untuk mencapai tujuan dan mempengaruhi untuk memperbaiki kinerjanya. 4)
Kurangnya perhatian terhadap pegawai yang memiliki kinerja yang tinggi sehingga cenderung dapat menurunkan kinerja baik secara individual maupun organisasi. 5) Kurangnya perhatian terhadap pegawai yang memiliki masa kerja lebih lama. 6) Kurangnya memahami analisis kebutuhan membuat kepuasan kerja pegawai dan kinerja pegawainya. 7) Kepuasan kerja dan kinerja pegawai yang masih rendah.

Masalah yang akan diteliti perlu dirumuskan dalam kalimat pernyataan jelas. Atas dasar itu, masalah yang akan diteliti dirumuskan sebagai berikut:

1. Bagaimana pengaruh gaya kepemimpinanterhadap kepuasan kerja pegawai Tenaga Kontrak pada Rumah Sakit Umum Daerah Kabupaten Ciamis?

2. Bagaimana pengaruh kompensasiterhadap kepuasan kerja pegawai Tenaga Kontrak pada Rumah Sakit Umum Daerah Kabupaten Ciamis?

3. Bagaimana pengaruh gaya kepemimpinanterhadap kinerja pegawai Tenaga Kontrak pada Rumah Sakit Umum Daerah Kabupaten Ciamis?

4. Bagaimana pengaruh kompensasiterhadap kinerja pegawai Tenaga Kontrak pada Rumah Sakit Umum Daerah Kabupaten Ciamis?

5. Bagaimana pengaruh gaya kepemimpinandankompensasiterhadap kinerja melalui kepuasan kerja pegawai Tenaga Kontrak pada Rumah Sakit Umum Daerah Kabupaten Ciamis?

\section{METODOLOGI}

\subsection{Metode Penelitian yang Digunakan}

Metode merupakan cara utama yang digunakan untuk mencapai suatu tujuan. Dalam penelitian ini metode yang digunakan adalah metode deskriptif. Pemilihan metoda tersebut didasarkan pada pendapat Surakhmad (1994:139) bahwa 
"Penyelidikan deskriptif tertuju pada pemecahan masalah yang ada pada masasekarang". Metode ini mencakup berbagai aspek diantaranyamengumpulkan bahan, menganalisis dan mengklasifikasi data.

\section{2 Sumber dan Teknik Pengumpulan Data}

Data yang digunakan dalam penelitian ini meliputi data primer dan sekunder. Jumlah sampel yang akan dijadikan responden dalam penelitian ini adalah sebanyak 70 orang karyawan Tenaga Kontrak (NonPNS) pada Rumah Sakit Umum Daerah Kabupaten Ciamis. Untuk menentukan dan memilih 70 sampel dari 235 populasi, digunakan teknik sampling yaitu Simple Random Sampling (SRS) atau sampel acak sederhana.

Teknik-teknik yang digunakan dalam penelitian ini adalah sebagai berikut: 1) Studi pustaka, 2) Penelitian Lapangan (Kuisioner, Dokumentasi dan Observasi).

\subsection{Teknik Analisis Data}

Teknik analisis data yang digunakan meliputi : Analisis Regresi Linear Sederhana, Analisis Regresi Linear Berganda, Analisis Koefisien Korelasi Sederhana, Analisis Koefisien Korelasi Berganda, Uji Koefisien Determinasi, dan Uji Hipotesis.

\section{HASIL DAN PEMBAHASAN}

\subsection{Pengaruh Gaya Kepemimpinan dan Kompensasi terhadap Kepuasan Kerja pada RSUD Kabupaten Ciamis}

Berdasarkan hasil penelitian diketahui bahwa terdapat pengaruh gaya kepemimpinandan kompensasi terhadap kepuasan kerja. Ini terbukti dari hasil perhitungan nilai korelasi sebesar 0,448 antara gaya kepemimpinan $\left(\mathrm{X}_{1}\right)$, kompensasi $\left(\mathrm{X}_{2}\right)$ dan kepuasan kerja $\left(\mathrm{Y}_{1}\right)$ yang menunjukkan adanya hubungan yang sedang, dengan tingkat pengaruh sebesar
20,10\%, menunjukkan bahwa kepuasan kerja pegawai Tenaga Kontrak pada RSUD Kabupaten Ciamis dipengaruhi oleh gaya kepemimpinan dan kompensasi sebesar $20,10 \%$, sedangkan sisanya 79,90\% (100$79,90)$ adalah koefisien non determinasi menunjukkan faktor lain diluar gaya kepemimpinan dan kompensasi.

\subsection{Pengaruh Gaya Kepemimpinandan Kompensasi terhadap Kinerja pada RSUD Kabupaten Ciamis}

Berdasarkan hasil penelitian diketahui bahwa terdapat pengaruh gaya kepemimpinandan kompensasi terhadap kinerja. Ini terbukti dari hasil perhitungan nilai korelasi sebesar 0,456 antara gaya kepemimpinan $\left(\mathrm{X}_{1}\right)$, kompensasi $\left(\mathrm{X}_{2}\right)$ dan kinerja $\left(\mathrm{Y}_{2}\right)$ yang menunjukkan adanya hubungan yang sedang, dengan tingkat pengaruh sebesar $20,10 \%$, menunjukkan bahwa kepuasan kerja pegawai Tenaga Kontrak pada RSUD Kabupaten Ciamis dipengaruhi oleh gaya kepemimpinan dan kompensasi sebesar 20,80\%, sedangkan sisanya $\quad 79,20 \% \quad(100-79,20) \quad$ adalah koefisien non determinasi menunjukkan faktor lain diluar gaya kepemimpinan dan kompensasi.

\subsection{Pengaruh Gaya Kepemimpinandan Kompensasi terhadap Kepuasan Kerja dan Kinerja pada RSUD Kabupaten Ciamis}

Berdasarkan hasil penelitian diketahui bahwa terdapat pengaruh gaya kepemimpinandan kompensasi terhadap kepuasan kerja dan kinerja. Ini terbukti dari hasil perhitungan nilai korelasi sebesar 0,799 antara gaya kepemimpinan $\left(X_{1}\right)$, kompensasi $\left(\mathrm{X}_{2}\right)$ dan kinerja $\left(\mathrm{Y}_{2}\right)$ yang menunjukkan adanya hubungan yang kuat, dengan tingkat pengaruh sebesar $63,84 \%$, menunjukkan bahwa kepuasan kerjadan kinerja dipengaruhi oleh gaya kepemimpinan dan kompensasi sebesar $63,84 \%$, sedangkan sisanya $36,16 \%$ (100$63,84)$ adalah koefisien non determinasi 
menunjukkan faktor lain diluar gaya kepemimpinan dan kompensasi

\section{SIMPULAN}

Berdasarkan pembahasan sebagaimana telah diuraikan sebelumnya, maka penulis mengambil simpulan sebagai berikut:

1. Gaya kepemimpinan berpengaruh terhadap kepuasan kerja, sehingga hipotesis yang diajukan diterima karena nilai t hitung lebih besar dari t table artinya apabila gaya kepemimpinan baik, maka kepuasan kerja akan baik.Begitupun sebaliknya apabila gaya kepemimpinan kurang baik, semakin kurang baik pula kepuasan kerja pegawai Tenaga Kontrak pada RSUD Kabupaten Ciamis.

2. Kompensasi berpengaruh terhadap kepuasan kerja, sehingga hipotesis yang diajukan diterima karena nilai t hitung lebih besar dari t table artinya apabila kompensasi baik, maka kepuasan kerja akan baik. Begitu pun sebaliknya apabila kompensasi kurang baik, semakin kurang baik pula kepuasan kerja pegawai Tenaga Kontrak pada RSUD Kabupaten Ciamis.

3. Gaya kepemimpinan berpengaruh terhadap kinerja, sehingga hipotesis yang diajukan diterima karena nilai $t$ hitung lebih besar dari t table artinya apabila gaya kepemimpinan baik, maka kinerja akan meningkat/tinggi. Begitupun sebaliknya apabila gaya kepemimpinan, semakin rendah/kurang baik pula kinerja pegawai Tenaga Kontrak pada RSUD KabupatenCiamis.

4. Kompensasi berpengaruh terhadap kinerja, sehingga hipotesis yang diajukan diterima karena nilai t hitung lebih besar dari t table artinya apabila kompensasi baik, maka kinerja akan meningkat/tinggi. Begitupun sebaliknya apabila kompensasi, semakin rendah/kurang baik pula kinerja pegawai Tenaga Kontrak pada RSUD Kabupaten Ciamis.

5. Gaya kepemimpinan dan kompensasi berpengaruh terhadap kinerja melalui kepuasan kerja, sehingga hipotesis yang diajukan diterima karena nilai t hitung lebih besar dari t table artinya apabila gaya kepemimpinan dan kompensasi baik, maka kepuasan kerja dan kinerja akan meningkat/tinggi. Begitupun sebaliknya apabila gaya kepemimpinan dan kompensasi kurang baik, semakin rendah/kurang baik pula kepuasan kerja dan kinerja pegawai Tenaga Kontrak pada RSUD KabupatenCiamis.

\section{DAFTAR PUSTAKA}

Arikunto, Suharsimi, (2006). Prosedur Penelitian Suatu Pendekatan Praktis. Jakarta: Grasindo.

Dessler, Gary, (2004). Manajemen Sumber Daya Manusia. Jakarta: Indeks

Handoko, T. Hani, (2001). Manajemen Personalia Sumber Daya Manusia. Yogyakarta: BFEE.

Hasibuan, Malayu S. P., (2010). Manajemen Dasar, Pengertian dan Masalah. Jakarta: PT. Bumi Aksara

Husein, Umar, (2003). Riset Sumber Daya Manusia. Jakarta. PT. Gramedia Pustaka Utama.

Luthan, Fred, (2006). Perilaku Organisasi. Yogyakarta: Andi.

Surakhmad, W., (1994). Pengantar Ilmiah Dasar, Metode dan Teknik. 